\title{
Kiai's Leadership in Managing Human Resources
}

\author{
Syahrul, Mukhneri Mukhtar, Maruf Akbar \\ Postgraduate Program \\ Universitas Negeri Jakarta \\ Jakarta, Indonesia \\ syahrul_mp13s3@mahasiswa.unj.ac.id
}

\begin{abstract}
The focus of this article review is Kiai's leadership in managing human resources at a modern boy boarding school in Southeast Sulawesi. The purpose of the study is to explore Kiai's leadership practices in aspects: 1) human resource planning; 2) organization of human resources; 3) leadership of human resources; and 4) supervision of human resources. Through a qualitative-descriptive approach, this study obtained findings including: 1) Kiai's leadership in human resource planning is carried out in the segments of students, teachers, and caregivers; 2) organizing human resources applied in the form of class division, dormitory, empowerment of talent-talent institutions, teacher empowerment in various activities; 3) leadership of human resources is indicated by the involvement of Kiai in various activities of students and teachers; 4) supervision of human resources is carried out by empowering clerical organizations and active involvement of students in enforcing discipline.
\end{abstract}

Keywords-Kiai's leadership; human resource management; boarding school

\section{INTRODUCTION}

Gontor modern boarding school is one of the largest Islamic education institutions in Indonesia. Its magnitude is not only seen in the distribution of alumni in various fields of national life, but also in widening the wings of the organization which reaches various regions in Indonesia. In this context, Gontor modern boarding school is the largest "boarding school corporation" in Indonesia [1]. On the other hand, various Islamic boarding schools in Indonesia are still busy discussing internal issues such as quality, modernization and the ability to face very rapid global developments. The theme of revitalization often arises from this phenomenon [2], including the demands for reform and reconstruction of Islamic education and Islamic education institutions, in front of the inclusive character of Islamic education [3]. The universal nature of Islam inherent in boarding school education must be demonstrated in world-oriented institutional management. Therefore, educational leaders must collaborate with the world community [4], dare to face the latest development [5], and adapt the system or latest methods [6].

Under these conditions, Gontor modern boarding school is required not only to produce graduates to take part in the wider community, but also to prepare human resources as the organization's progressions. The existence of various Gontor modern boarding school branches and various internal activities, requires a good arrangement to ensure the implementation of activities as well. The quality of good human resources will guarantee the management of quality boarding schools. So it becomes a demand for boarding school to have continuous quality commitments [7].

The plurality of citizenship backgrounds of Gontor modern boarding school, with various roles in sub-organizations, requires a unifying figure who has a strong influence, in this case Kiai. Unlike other boarding school that highlight the Kiai's personal charisma in carrying out leadership. At Gontor modern boarding school leadership was born out of a regular regeneration process, from students, during service, to becoming a teacher, and finally trusted to lead certain organizational units. Therefore, every Kiai who has the trust to lead Gontor modern boarding school's sub-organization has a tiered experience and a lead readiness track record. So, elitism is often aimed at Kiai figures [8], cannot be proven at Gontor 7 modern boy boarding school.

This article aims to provide an overview of the leadership of the Kiai in the Management of Human Resources in Gontor 7 modern boy boarding school, Southeast Sulawesi, with subfocus: 1) human resource planning; 2) organizing human resources; 3) leadership of human resources; and 4) supervision of human resources.

\section{METHOD}

\section{A. Method}

Deepening of the focus of this study uses a qualitative approach with descriptive methods. Field facts about Kiai's leadership practices in HR management at Gontor 7 modern boy boarding school will be dissected using relevant theories. Data collection is done through the process of interviews, observations, and document studies. After the data is collected, an analysis is carried out starting from the stages of reduction, presentation, and conclusion. Testing the validity of the data is also done by extending observations, increasing perseverance, triangulation, and checking informants.

\section{B. Materials}

The study material was initially obtained from the grand tour process, which was later developed into a research topic. The expansion of material is carried out by reading relevant literature, magazines and research. Next, an empirical review is carried out so that primary data and secondary data are obtained. The selection of informants is done by determining key informants, making it easier to get richer informants and data. 


\section{RESULTS AND DISCUSSION}

Leadership is a condition of institutional activities that involves the interaction of leaders and followers. The interaction model is largely determined by the leadership style that is built on an organization [4]. In the leadership of the Kiai in Gontor 7 modern boy boarding school, there is a scope of leadership that must be obeyed by whoever holds the top position. The limit is in the fourteen points of Gontor modern boarding school's leadership qualifications, namely: 1) sincerity; 2) initiative; 3) network work; 4) can be trusted; 5) hard and earnest work; 6) master problems and solutions; 7) high integration; 8) high courage and no fear of risk; 9) honest and open; 10) ready to sacrifice; 11) firm; 12) smart in seeing, hearing, evaluating, evaluating, deciding, and completing; 13) able to communicate; 14) both in relation to God and human relations [1]. With these qualifications, Gontor's leaders continued to develop, gaining public trust, without leaving the boarding school culture. Unlike the Lirboyo boarding school (for example) that cannot be separated from the shadow of the greatness of its predecessors, especially KH. Hasyim Asy'ari [9]. Another thing with the existence of Kiai in Madurese people, who attach to it all kinds of privileges, is considered versatile, so it is weak in empowering boarding school residents. The position of the Kiai in this context is primus interpares, a single figure full of charisma where the people depend [10].

The leadership qualifications above are emitted in various cottage activities, one of which is in the management of human resources. The meaning of human resources in Gontor 7 modern boy boarding school is Kiai, Teachers, Caregivers, and Students. The four components have their respective roles in order to achieve Gontor modern boarding school's goals. The findings related to the practice of human resource management are described as follows:

\section{A. Human Resource Planning}

Human resource planning in Gontor 7 modern boy boarding school Southeast Sulawesi can be categorized into four parts, namely: 1) students; 2) religious teacher; 3) caregivers. First, human resource planning in the students' segment is carried out by conducting a needs analysis, usually limited to certain quota because this relates to the availability of educational infrastructure facilities. Second, planning at the teaching staff level or Teachers is done by paying attention to the number of students and the scientific fields needed. Even so, because at Gontor modern boarding school had a prospective teacher program through KMI, the teaching staff was recruited from KMI graduates who had gone through a service period in one branch of Gontor modern boarding school for at least one year. Third, at the level of caregivers, recruitment is carried out by paying attention to the track record of service and especially the commitment of "selfconfession" to Gontor modern boarding school. The process of human resource planning is led by Kiai according to the mechanism in force at Gontor modern boarding school.

The approach to work productivity encourages formulation of plans based on situation analysis, design of increasing work productivity, creating awareness of productivity, implementing programs, and evaluating and feedback [11].
Human resources must be positioned as valuable assets, so that recruitment must be carried out in a quality manner, so that the birth of human resources matches the designation (the right man on the right place) [12]. In this case, competent leaders are needed [13], able to distinguish between leadership and management [14], that can make a change in educational leadership style [15].

\section{B. Organizing Human Resources}

Students Gontor 7 modern boy boarding school was divided into two levels, namely Sullamu Muta'allimin at junior high school level and kulliyatul Mu'allimin Al Islamiyah abbreviated as KMI. The division of student groups was carried out starting from the arrangement of the classes to the distribution of dormitories. Each class is led by a teacher as a homeroom teacher, as well as each dormitory fostered by an teachers. In addition, the students were given the freedom to develop their interests and talents through organizations such as scouts, martial arts, theater, calligraphy, journalism, language, sports, and OPPM activists.

At the Teachers level, in addition to accompanying students in classrooms and dormitories, they become coaches of student activities in various organizations in Gontor 7 modern boy boarding school. Important parts of the cottage activities that determine the running of activities are carried out specifically by the cleric team, such as the court enforcing discipline for violating regulations.

Caregivers together with Kiai are tasked with ensuring that Gontor 7 modern boy boarding school programs run according to plan, ensuring the implementation of various regulations consistently. Another task is to think of innovations can be developed for the progress of Gontor 7 modern boy boarding school.

Organizing is the process of dividing work and who does it. A more important consideration is the competence of the work implementing officer. The motto of the right man on the right place is highly upheld at this stage. The practice of organizing in organizing Islamic boarding schools can be seen in the Darul Ulum Islamic Boarding School which is fully conducted by the Board of Islamic Boarding Schools (MPP) determined by the general secretary. Furthermore carried out departmentalization, delegation of authority, range of control, and the formation of a cottage assembly structure [16]. The issue of talent must be the focus of the leader, so that the organizing process runs as it should [17]. Performance improvement can be achieved through appropriate education and training [18]

\section{Human Resource Leadership}

The various plans set out in the lodge mechanism, as well as the arrangements of the executors, were driven by the presence of the Kiai in various activities of Gontor 7 modern boy boarding school. Not only ceremonial, Kiai is always together with religious teachers and students, on the soccer field, martial arts training, art studios, priests in mosques, and community activities.

The presence of a Kiai in every momentum will add personal closeness between Kiai and boarding school residents. Consistency in self-involvement by a leader will 
have a strong influence on members, so it can be driven to achieve organizational goals. This way of thinking confirms the definition of leadership that emphasizes the power of influence, especially individually, not structural influences [19]. Responsibility is a hallmark of performance-oriented leaders [20], in addition, sensitivity to humanitarian issues such as gender [21] and harmony [22].

\section{Human Resource Supervision}

The activities carried out by students, teachers, and caregivers took place within the framework of the Gontor 7 modern boy boarding school organization. The students, from the very beginning entering the environment of Gontor 7 modern boy boarding school, had pledged compliance with the applicable regulations, not only oral statements but also embedded in the students' heart. Every disciplinary violation is directly punished at the scene. Violation of language rules will be tried in the language driving court, as well as the caretaker court for serious violations.

One unique supervision technique is "Jasus", which is a chain of intelligence surveillance models, where every student who commits a violation will be given a jasus card which serves to record violations committed by other students. This method is very massive because every student is very likely a jasus, so the students will be very careful in behaving.

Meanwhile the religious teachers will receive direct supervision from the board of caregivers and Kiai. The aspects of supervision are related to consistency in carrying out tasks and functions, both in class and in the formation of students. Including the ability to develop themselves and the students. This is useful in order to develop their profession as religious teachers.

The process of supervision in an institution is aimed at achieving goals effectively and efficiently [23]. Supervision in various forms is aimed at improving quality and productivity. But human supervision cannot only use one approach, let alone only be structural. It is also important to pay attention to varied supervision that respects personal, and humane [24].

In other Islamic boarding schools, such as the Al-Jauhar boarding school, supervision by the leadership is still guided by formal supervision principles such as observation, instruction, principle, measurement, correction, monitoring, assessment, and standard setting [25]. However, supervision is an important factor in ensuring the effectiveness of school administration [26].

\section{CONCLUSION}

Based on the results of the research and discussion above, the conclusions that can be drawn are: first, Kiai's leadership in human resource planning at Gontor 7 modern boy boarding school is carried out in stages, ranging from students, teachers, to caregivers. The steps of human resource planning are implemented through needs analysis, availability of facilities and infrastructure, teacher qualifications needed, and commitment to surrender to the progress of the institution. Second, organizing human resources is carried out in the form of distribution of students in the classroom and distribution of dormitories, assignment of homeroom teachers and boarders, assigning a board of caregivers to monitor cottage activities and development ideas. In addition, it is encouraging students to be involved in interest-talent development activities through internally available containers. Likewise, Teachers becomes a partner in every student activity. Third, the leadership of human resources was demonstrated by Kiai with involvement in every activity of the citizens of Gontor 7 modern boy boarding school. Fourth, supervision of human resources is carried out in the form of empowering the teacher council and students in carrying out chain supervision.

Based on the conclusions of the study above, the suggestions that can be conveyed in the management of educational institutions widely are: first, the need for comprehensive human resource planning, analyzing various aspects, so that they are right on target. Second, organizing human resources should pay attention to the development of students, empowering teachers and students. Third, the need for substantive leaders, not only present ceremonially. Fourth, the need for effective supervision, not frightening, but pervades the awareness of the school community.

\section{ACKNOWLEDGMENT}

This research was carried out because of support from the leadership of Kendari IAIN, especially the Institute for Research and Community Service (LPPM). Thank you for this institutional support, I hope this article becomes one of the reasons for the improvement of the image of IAIN Kendari.

\section{REFERENCES}

[1] S. Syahrul, M. Mukhtar, and M. Akbar, "Construction of Organizational Culture at Gontor modern boarding school VII Putera, South Konawe District, Southeast Sulawesi," Int. J. Adv. Eng. Manag. Res., vol. 3, no. 5, pp. 25-40, 2018.

[2] M. A. Hair, "Manajemen Pembaharuan Pesantren di Tengah Tantangan Kehidupan Masyarakat Global," Fikrotuna, vol. 4, no. 2, pp. 1-17, 2017.

[3] N. R. Hayati, "Manajemen Pesantren dalam Menghadapi Dunia Global," Tarbawi, pp. 97-106, 2015.

[4] S. R. Ninković and O. Knežević Florić, "Transformational school leadership and teacher self-efficacy as predictors of perceived collective teacher efficacy," Educ. Manag. Adm. Leadersh., vol. 46, no. 1, pp. 49-64, 2018.

[5] K. K. Brant and S. L. Castro, "You can ' $t$ ignore millennials : Needed changes and a new way forward in entitlement research," Hum. Resour. Manag. J., vol. 2025, no. June 2017, pp. 1-12, 2019.

[6] M. Boylan, "Enabling adaptive system leadership: Teachers leading professional development," Educ. Manag. Adm. Leadersh., vol. 46, no. 1, pp. 86-106, 2018.

[7] T. K. Nga and T. T. K. Trang, "Impacting Deposit Service Quality On Customer' Satisfaction: A Case of Bidv In Can Tho," Glob. J. Hum. Resour. Manag., vol. 7, no. 2, pp. 18-26, 2019.

[8] M. T. Ilahi, “Kiai: Figur Elite Pesantren," Ibda', pp. 137-148, 2014.

[9] M. Mardiyah, "Kepemimpinan Kiai dalam Memelihara Budaya Organisasi di Pondok Modern Gontor , Lirboyo Kediri, dan Pesantren T ebuireng Jombang," Tsaqafah, vol. 8, no. 1, p. 67, 2012.

[10] E. Susanto, "Kepemimpinan (Kharismatik) Kyai dalam Perspektif Masyarakat Madura," Karsa, vol. XI, no. 1, pp. 30-40, 2017.

[11] S. Samsuni, "Manajemen Sumber Daya Manusia." Al Falah, pp. 113124, 2017. 
[12] B. Setiani, "Kajian sumber daya manusia dalam proses rekrutmen tenaga kerja di perusahaan," J. Ilm. WIDYA, vol. 1, no. 1, pp. 38-44, 2013.

[13] M. Lopez-Delgado, "Looking for Competent School Leaders for Indigenous Schools: The New System to Appoint School Leaders in Mexico," Int. J. Educ. Policy Leadersh., vol. 13, no. 9, 2018.

[14] T. Bush, "Distinguishing between educational leadership and management: Compatible or incompatible constructs?," Educ. Manag. Adm. Leadersh., vol. 47, no. 4, pp. 501-503, 2019.

[15] T. Bush, "Distributed leadership and bureaucracy: Changing fashions in educational leadership," Educ. Manag. Adm. Leadersh., vol. 47, no. 1, pp. 3-4, 2019

[16] F. Auliya, "Pengorganisasian Pondok Pesantren Darul 'Ulum Rejoso Peterongan Jombang Jawa Timur," Skripsi UIN Sunan Kalijaga, pp. 1$88,2013$.

[17] 2011 Bruce, "A Proposed Model To Measure The Effect of The Quality of Working Life (QWL) On Talent Management In Organization: An Empirical Study On The Zues Canal Authority," J. Chem. Inf. Model., vol. 53, no. 9, pp. 1689-1699, 2013.

[18] C. Sothy, "The Impact of Training dan Development On Employee Performance: A Case Study of Selected Private Secondary Schools In Phnom Penh Cambodia," Glob. J. Hum. Resour. Manag., vol. 3, no. 9, pp. 40-49, 2019

[19] S. P. Robbins and M. Coulter, Management. Prentice Hall, 2012.

[20] T. Bush, "School leaders and accountability: Performance or performativity?," Educ. Manag. Adm. Leadersh., vol. 47, no. 2, pp. 167-169, 2019.

[21] J. Sebastian, "Gender differences in participatory leadership: An examination of principals' time spent working with others," Int. J. Educ. Policy Leadersh., vol. 12, no. 8, 2018.

[22] N. . Onwochei, M. . Uzoigwe, and O. Ajino, "MANAGING LABOUR UNIONISM FOR INDUSTRIAL HARMONY AND ACADEMIC,' Glob. J. Hum. Resour. Manag., vol. 7, no. 4, pp. 1-15, 2019.

[23] et al., "Tinker, Tailor, Supervisor, Spy: Lessons Learned from Distant Supervision,” J. Educ. Superv., vol. 2, no. 1, pp. 78-97, 2019.

[24] S. Haberlin, "Something Always Works: A Self-Study of Strengthsbased Coaching in Supervision," J. Educ. Superv., vol. 2, no. 1, pp. 38 $57,2019$.

[25] N. Yunita, "Sistem Pengawasan Pimpinan Pondok Pesantren Al-Jauhar terhadap Etika Santri,” Repos. UIN Suska, pp. 1-10, 2015.

[26] B. McCormack, L. Baecher, and A. Cuenca, "University-Based Teacher Supervisors: Their Voices, Their Dilemmas," J. Educ. Superv., vol. 2 , no. 1, pp. 22-37, 2019. 